\title{
A New Species of the Genus Garra Hamilton, 1822 from the Chindwin Basin of Manipur, India (Teleostei: Cyprinidae: Labeoninae)
}

\author{
Bungdon Shangningam and Waikhom Vishwanath \\ Department of Life Sciences, Manipur University, Manipur, Canchipur 795003, India \\ Correspondence should be addressed to Waikhom Vishwanath, wvnath@gmail.com \\ Received 18 November 2011; Accepted 14 December 2011 \\ Academic Editors: M. Cucco, J. Gautrais, and L. Kaczmarek
}

Copyright (C) 2012 B. Shangningam and W. Vishwanath. This is an open access article distributed under the Creative Commons Attribution License, which permits unrestricted use, distribution, and reproduction in any medium, provided the original work is properly cited.

Garra namyaensis sp. nov., a new cyprinid fish, is described from the Chindwin River basin in Manipur, India. It is distinguished from its congeners in having a unique combination of the following characters: smoothly rounded snout tip with a prominent rostral lobe, chest and abdominal region with scales, dorsal fin with a black band near the posterior margin, and caudal fin with a distinct W-shaped black band.

\section{Introduction}

Fishes of the genus Garra Hamilton, 1822 are characteristic in having a more or less well-developed suctorial disc on the undersurface just behind the mouth. These fishes inhabit rapid running waters and maintain themselves against swift currents by clinging to the substratum, mainly by means of their suctorial disc but also by the horizontally placed paired fins, especially the pectorals [1]. The genus is widely distributed from Southern China, across Southeast Asia, India, and the Middle East to Northern and Central Africa [2]. There are more than 170 nominal species of Garra [3].

Recent collection of freshwater fishes from the Namya River of Ukhrul district, Manipur, Chindwin basin, included an undescribed species of Garra, which is described herein as Garra namaensis sp. nov.

\section{Materials and Methods}

The description is based on formalin-preserved specimens. Counts, measurements, and terminology follow Kullander and Fang [2], and that of head depth follows Menon [1]. Measurements were taken point to point with dial calliper to the nearest $0.1 \mathrm{~mm}$. The number in round brackets of parentheses after a specific count indicates the number of specimens examined. Terminology used for description of disc is reported by Zhang et al. [4]. Fin rays and numbers of scales were counted under a stereo-zoom transmitted light microscope. Lateral line scale is counted from the anteriormost pored scale in contact with the shoulder girdle to the last posteriormost pored scale on the caudal fin. Transversescale rows above the lateral line are counted from the dorsalfin origin to lateral line obliquely ventrad and caudad, and those below lateral line, from the pelvic-fin origin obliquely dorsad and rostrad to lateral line. Osteological structures were observed in a cleared and alizarin-stained specimen. Vertebral counts follow Roberts [5], and scale counts follow Kottelat [6]. Morphometric measurement data are given in percentages of standard length (SL), head length (HL), pelvic-anal distance, and head and caudal peduncle depth. Specimens examined for the study are deposited in the Manipur University Museum of Fishes (MUMF).

\subsection{Taxonomy}

Garra namyaensis sp. nov. (Figure 1)

\subsubsection{Type Material}

Holotype. India, Manipur state, Ukhrul district, Namya River, close to Indo-Myanmar border, $72.5 \mathrm{~mm} \mathrm{SL} ; 24^{\circ} 52^{\prime} \mathrm{N}$ 94³9'E; Shangningam et al., 18.IV.2011 (MUMF 12042). 

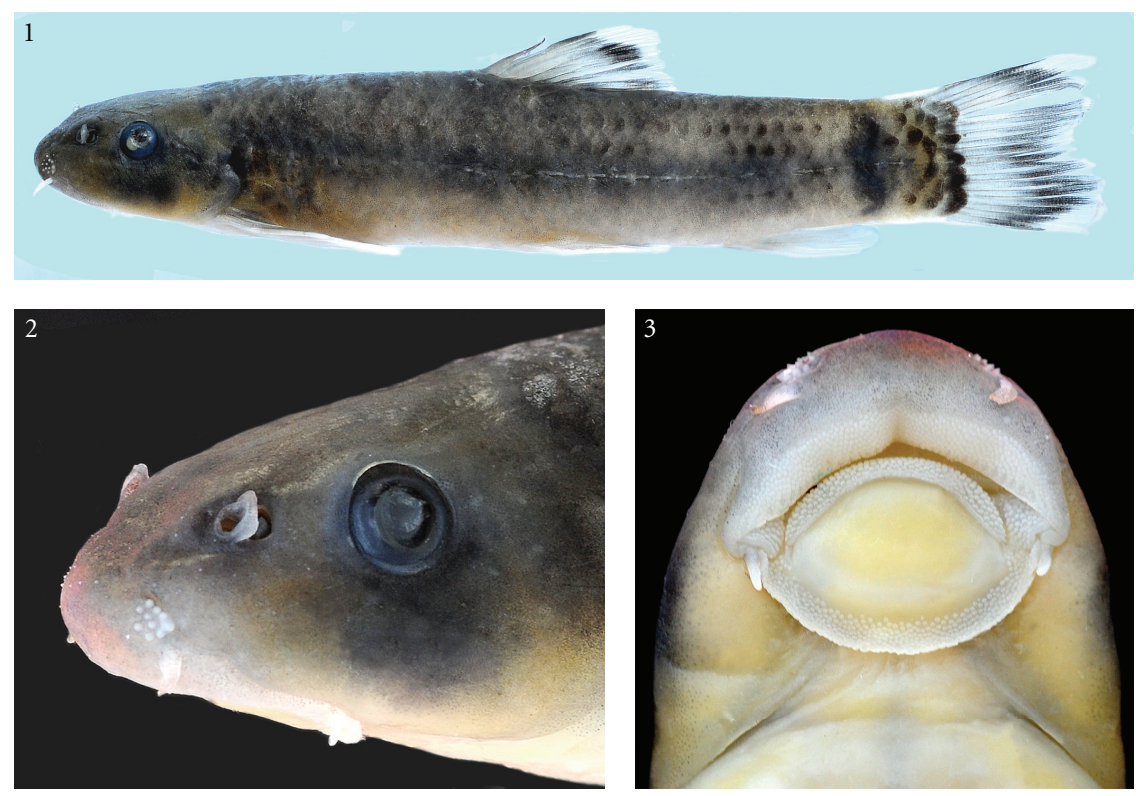

FIgURE 1: Garra namaensis, new species, holotype: (1) side view; (2) side view of snout showing rostral lobe; (3) mental disc.

Paratypes. 4 spec. same data as holotype, 28.1-53.9 mm SL (MUMF 12041,12043, 12044, 12045), one paratype (30.0 mm SL) dissected for osteology.

\section{Comparative Material}

Garra abhoyai. MUMF 6296-6305, 10 spec. 49.3-54.90 mm SL; India: Manipur, Phungdhar, Iril River.

G. lissorhynchus. MUMF 4163-4166, 4 spec. $58.0-91.5$ mm SL; India: Manipur: Tamenglong district, Noney, Iyei River.

G. manipurensis. MUMF 4160-4162, 3 spec. 44.0-70.0 mm SL; India: Manipur: Tamenglong district, Noney, Iyei River.

G. nambulica. MUMF 8004-8008, 5 spec. 53.8-76.2 mm SL; India: Manipur: Conchak Lok stream of Nambul River.

G. paralissorhynchus. MUMF 5103-5106, 4 spec. 53.763.4 mm SL; India: Manipur: Churachandpur district, Khuga River.

2.1.2. Etymology. The species is named after its type locality: Namya River.

2.1.3. Diagnosis. A small species of Garra with smoothly rounded snout tip, prominent triangular-shaped rostral lobe with 10-11 strong, conical tubercles; proboscis and transverse groove absent; predorsal region, chest and abdomen scaled; two pairs of barbels, lateral line scales 31, circumpeduncular scales 14. Transverse-scale rows 3.5/1/3.5. Gill rakers are nine. Total number of vertebrae is 32 . Dorsal fin with broad black band is near the posterior margin and a distinct $\mathrm{W}$-shaped broad black band in caudal fin.
2.1.4. Description. Morphometric data of the holotype and four paratypes are given in Table 1. Body elongate, cylindrical anteriorly, gradually compressed behind dorsal fin base, body depth almost uniform. Dorsal profile of body slightly convex from tip of the supraoccipital process to dorsal fin origin. Dorsal-fin base almost straight, slightly sloping posteroventrally. Profile from posterior end of dorsal-fin base to caudal fin base slightly concave. Ventral profile of body slightly convex from pectoral to pelvic fin origin, straight from pelvic to anal-fin origin. Anal-fin base nearly straight, posterior dorsally inclined. Head moderately large, depressed with a slightly convex interorbital space; height less than its length, width greater than height. Snout broadly rounded with minute tubercles. Rostral lobe well-developed with tubercles 10(4)-11(1) in patch anterodorsal to the base of anterior barbels in about three irregular rows. Tubercles dense and pointed. Eyes placed dorsolaterally in the posterior half of head.

Two pairs of barbels: rostral: located anterolaterally, as long as eye diameter; maxillary: at the corner of mouth, shorter than rostral; anterior barbels short, extending to margin of rostral cap. Rostral cap well-developed; curved ventrally and connected with lower lip at the corners of mouth (Figure 1(2)). Upper jaw entirely covered by rostral cap. Lower lip modified into a mental adhesive disc. Disc elliptical, shorter than its width and narrower than head width through roots of maxillary barbels; anterior margin modified to form a transverse, fleshy, and crescentic skin fold covered by numerous tiny papillae; anteriorly separated from lower jaw by a groove running along lower jaw and posteriorly, from the central callous pad by a groove. Lateral and posterior margins of the disc surrounding central callous pad papillate and free; posteriormost margin extending a little beyond vertical from anterior margin of eye (Figure 1(3)). 
TABle 1: Morphometric data of holotype and paratypes for Garra namyaensis sp. nov. (holotype and four paratypes).

\begin{tabular}{|c|c|c|c|c|}
\hline & $\begin{array}{c}\text { Holotype MUMF } \\
12 \mathrm{O} 42 \\
\end{array}$ & Range & Mean & SD \\
\hline Standard length $(\mathrm{mm})$ & 72.5 & $28.1-72.5$ & & \\
\hline \multicolumn{5}{|l|}{$\begin{array}{l}\text { Percentage of standard } \\
\text { length }\end{array}$} \\
\hline Body depth & 19.0 & $19.0-21.0$ & 20.0 & 0.8 \\
\hline Head length & 22.6 & $20.0-25.0$ & 24.3 & 1.0 \\
\hline Head depth & 15.2 & $14.0-16.3$ & 15.2 & 1.0 \\
\hline Head width & 18.0 & $17.0-20.0$ & 19.0 & 1.3 \\
\hline Dorsal fin length & 21.0 & $21.0-23.1$ & 23.1 & 1.8 \\
\hline Pectoral fin length & 23.0 & $23.0-25.0$ & 24.0 & 0.8 \\
\hline Pelvic fin length & 19.0 & $18.3-20.0$ & 19.0 & 0.6 \\
\hline Anal fin length & 19.4 & $17.4-21.0$ & 20.0 & 1.3 \\
\hline $\begin{array}{l}\text { Length of caudal } \\
\text { peduncle }\end{array}$ & 15.0 & $13.0-15.2$ & 14.0 & 1.0 \\
\hline $\begin{array}{l}\text { Depth of caudal } \\
\text { peduncle }\end{array}$ & 13.0 & $13.0-15.0$ & 13.4 & 1.1 \\
\hline Predorsal length & 50.3 & $50.0-53.0$ & 51.0 & 1.2 \\
\hline Prepectoral length & 20.3 & $19.3-21.4$ & 20.5 & 0.8 \\
\hline Prepelvic length & 55.0 & $55.0-61.0$ & 57.4 & 2.4 \\
\hline Preanal length & 79.0 & $79.0-85.3$ & 81.3 & 2.7 \\
\hline \multicolumn{5}{|l|}{ Percentage of head length } \\
\hline Head depth & 67.0 & $54.3-83.0$ & 66.0 & 10.7 \\
\hline Snout length & 51.0 & $46.0-61.0$ & 51.4 & 5.8 \\
\hline Eye diameter & 15.0 & $15.0-25.4$ & 19.0 & 4.1 \\
\hline Interorbital width & 49.0 & $45.0-63.0$ & 50.0 & 7.3 \\
\hline Disc length & 34.0 & $34.0-44.0$ & 39.0 & 4.7 \\
\hline Disc width & 53.0 & $44.3-56.0$ & 52.0 & 4.4 \\
\hline Callous pad length & 23.2 & $21.1-34.0$ & 25.3 & 5.0 \\
\hline Callous pad width & 33.0 & $27.2-44.1$ & 34.6 & 6.1 \\
\hline \multicolumn{5}{|l|}{ Percentage of head depth } \\
\hline Head width & 118.2 & $118.2-126.2$ & 122.2 & 3.0 \\
\hline Body depth & 125.0 & $120.4-145.0$ & 131.0 & 9.3 \\
\hline \multicolumn{5}{|l|}{$\begin{array}{l}\text { Percentage of pelvic-anal } \\
\text { distance }\end{array}$} \\
\hline Anal-Vent distance & 33.1 & $28.0-33.3$ & 30.3 & 3.8 \\
\hline \multicolumn{5}{|l|}{$\begin{array}{l}\text { Percentage of caudal } \\
\text { peduncle depth }\end{array}$} \\
\hline Caudal peduncle length & 112.0 & $93.0-115.2$ & 104 & 9.6 \\
\hline
\end{tabular}

Dorsal fin with ii, 6.5(5) rays, inserted anterior to pelvic fin, highest point of the body at dorsal fin origin, first branched ray longest, posterior end at same level with that of pelvic, posterior margin of dorsal fin straight. Pectoral and pelvic fins extending horizontally. Pectoral fin with i, $12(5)$ rays, origin close to gill opening, with round posterior margin, fourth branched ray longest end of pectoral fin not reaching pelvic fin origin, separated from it by 6-7 scales. Pelvic fin with i, 7.5(5) rays, origin situated vertically at base of second branched ray of dorsal fin rays, end of pelvic fin surpassing the anus, second and third branched ray longest separated from anal-fin origin by 2(4)-3(1) scales, posterior margin round, and length of vent-anal-fin origin about 27.5$33.3 \%$ distance of pelvic to anal-fin origin. Anal fin with ii,
4.5 rays, distal margin slightly concave, posterior end of analfin not reaching of caudal fin base extends to mid of caudal peduncle, distance of anal-fin origin to caudal-fin base equal to or slightly smaller than that of anal-fin origin to pelvicfin origin, separated from pelvic fin origin by $8(4)-9(1)$ scales. Vent closer to anal-fin origin than to pelvic-fin origin, separated from anal-fin origin by 3(4)-4(1) scales. Caudal fin emarginated, upper lobe slightly longer than lower lobe, bearing $10+9(5)$ rays.

Lateral line complete with 31(5) scales. Scales in transverse row above lateral line and below lateral line from ventral fin origin 3.5(5) each. Circumpeduncular scale rows 14(5). Predorsal scales 13(5); scales arranged regularly, same size as flank scales. Both chest and belly scaled. Scales 


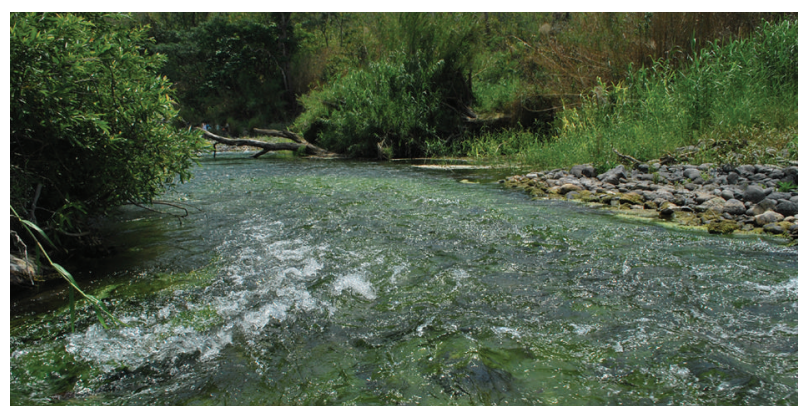

FIGURe 2: Namya River, type locality and habitat of Garra namaensis sp. nov.

between vent and anal-fin base 3(3)-4(2). Gill rakers nine. Total number of vertebrae 32, consisting of $22+10$ abdominal and caudal vertebrae.

2.1.5. Coloration. In $10 \%$ formalin, body dorsum is greyish brown, lighter posteriorly, dull greyish brown on caudal peduncle. Ventrally, head, pectoral, and pelvic fin bases are yellowish. Dark brown spot is immediately posterior to dorsal gill opening. Dorsal fin is basally yellowish white, dark black band near the posterior margin. Pectoral fin is basally yellowish with greyish submarginal band on anterior rays. Pelvic and anal-fins are greyish white. Caudal fin is with a distinct $\mathrm{W}$-shaped broad black band with lines of black spots anterior to its base.

In life, body background is greenish brown, with upper angle of gill opening with shining bluish shine. Fins are golden yellow. Dorsal fin is basally yellowish with broad black band near the posterior margins. Caudal fin is with a distinct $\mathrm{W}$-shaped blue black band.

2.1.6. Biology. The species inhabits swiftly flowing clear water with gravel bottom and lush green algal bloom (Figure 2). It was found adhering to rocks at the time of collection. Other species of fishes collected from the locality include species of Glyptothorax, Channa, Mastacembelus, Neolissochilus, Schistura, Tor, Puntius, and Balitora.

2.1.7. Distribution. Garra namyaensis sp. nov. is presently known from the Namya River, Chindwin basin (IndoMyanmar border) in Ukhrul district, Manipur state, India (Figure 3).

\section{Discussion}

Key to species of Garra in the Chindwin basin is given in Table 2. Among the 12 species of Garra reported by Hora [7] from the drainages of the Himalayan foothills, G. abhoyai Hora, 1921 is from the Chindwin basin. Menon [1] considered G. abhoyai as the junior synonym of G. rupecula (McClelland, 1839) which has been later revalidated and redescribed [8]. Later, G. paralissorhynchus Vishwanath and Shanta, 2005 [9] and G. nambulica Vishwanath and Joyshree, 2005 [10] have also been described from the Chindwin basin, Manipur.

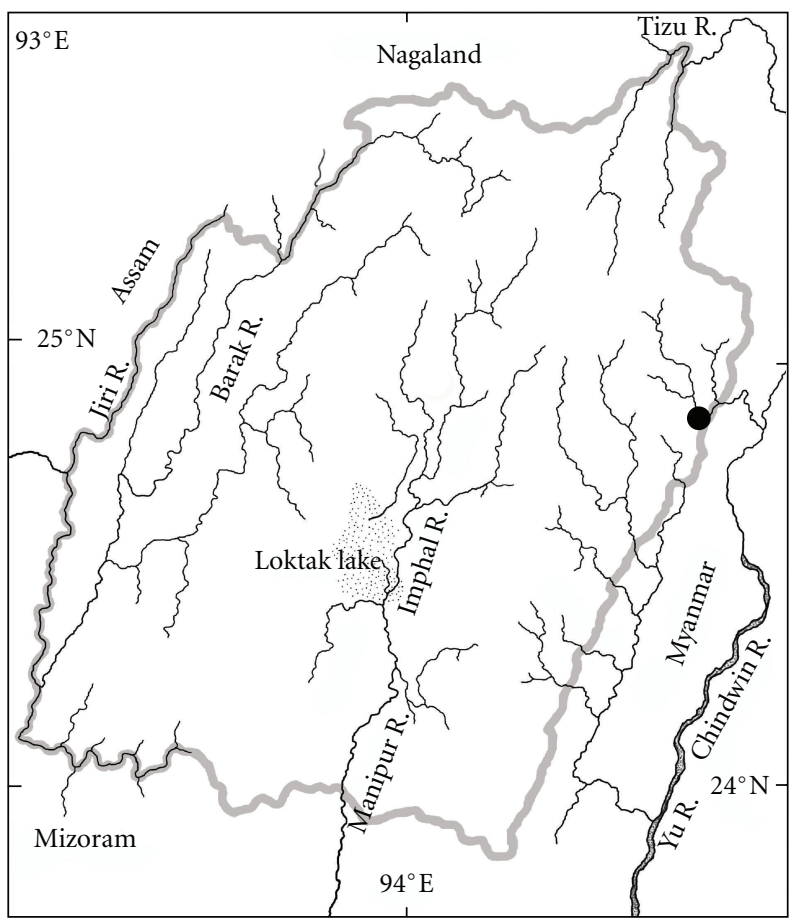

FIgURe 3: Map showing type locality of Garra namaensis sp. nov.

The new species under description shares similar characters with G. abhoyai, G. nambulica, and G. paralissorhynchus occurring in the Chindwin basin in having a dark black band on the posterior margin of the dorsal fin and a broad black W-shaped band on the caudal fin. Menon [1] grouped these fishes under Lissorhynchus complex based on the colour markings mentioned above. However, G. namyaensis sp. nov. is easily distinguished from the three congeners in the presence (versus absence) of a rostral lobe on the snout. It further differs from G. abhoyai in having 12 (versus 13) branched pectoral fin rays, scales on the chest and abdomen (versus naked), longer dorsal fin (21.0-22.2\% SL versus 14.211.5), and pectoral fin (22.5-24.7\% SL versus $20.0-21.5)$; from G. nambulica in having 31 (versus 34-35) scales on the lateral line, a longer snout (49.0-61.0\% HL versus $28.9-$ 32.9 ), a shorter disc (30.5-44.0\% HL versus 57.2-64.5), and scales on the chest and abdomen (versus naked); and from $G$. paralissorhynchus in having 12 (versus 11) branched pectoral fin rays, 19 (versus 17) caudal fin rays, 13 (versus 11-12) predorsal scales, and scales on the chest and abdomen (versus naked).

Of the seven species of Garra described from the Rakhine Yoma, Southern Myanmar by Kullander and Fang [2], two species, namely, G. flavatra Kullander and Fang, 2004 and G. poecilura Kullander and Fang, 2004, resemble G. namyaensis sp. nov. in having distinct coloured markings on the caudal fin. However, the new species is easily distinguished from G. flavatra in having a distinct W-shaped band (versus two vertical bars of irregular black spots) on the caudal fin, two (versus three) each of branched dorsal and anal-fin rays, 31 (versus 28) lateral line scales and 13 (versus 10) predorsal scales. G. namyaensis sp. nov, can also be distinguished 
Table 2: Key to Garra species of the Chindwin basin.

\begin{tabular}{|c|c|c|}
\hline \multirow{2}{*}{ (1) } & (i) Snout with proboscis & (2) \\
\hline & (ii) Snout without proboscis & (7) \\
\hline \multirow{2}{*}{ (2) } & (i) Proboscis well-developed & (3) \\
\hline & (ii) Proboscis incipient, represented by a truncate area in front of the nostrils & gravelyi \\
\hline \multirow{2}{*}{ (3) } & (i) Proboscis bilobed with one large & bispinosa \\
\hline & (ii) Proboscis unilobed or quadrate & $(4)$ \\
\hline \multirow{2}{*}{ (4) } & (i) Vent to anal distance more than $45 \%$ of pelvic to anal-fin distance & elongata \\
\hline & (ii) Vent to anal distance less than $40 \%$ of pelvic to anal-fin distance & (5) \\
\hline \multirow{2}{*}{ (5) } & (i) Simple dorsal fin rays two & litanensis \\
\hline & (ii) Simple dorsal fin rays four & (6) \\
\hline \multirow{2}{*}{ (6) } & (i) Lateral line scales 34 ; anus to anal distance $32.1-39.2 \%$ of pelvic to anal distance & rotundinasus \\
\hline & (ii) Lateral line scales $36-37$; anus to anal distance $22.8-28.3 \%$ of pelvic to anal distance & qiaojiensis \\
\hline \multirow{2}{*}{ (7) } & (i) Caudal fin with W-shaped black mark & (8) \\
\hline & (ii) Caudal fin without W-shaped black mark & (9) \\
\hline \multirow{2}{*}{ (8) } & (i) Caudal fin forked & nambulica \\
\hline & (ii) Caudal fin slightly emarginated & (10) \\
\hline \multirow{2}{*}{ (9) } & (i) Rostral lobe present & poecilura \\
\hline & (ii) Rostral lobe absent & $(11)$ \\
\hline \multirow{2}{*}{ (10) } & (i) Snout without tubercles & abhoyai \\
\hline & (ii) Snout with tubercles & $(14)$ \\
\hline \multirow{2}{*}{ (11) } & (i) Snout without barbels & imberbis \\
\hline & (ii) Snout with barbels & $(12)$ \\
\hline \multirow{2}{*}{ (12) } & (i) Lateral line scales 30-31 & spilota \\
\hline & (ii) Lateral line scales more than $37-38$ & (13) \\
\hline \multirow{2}{*}{ (13) } & (i) Simple dorsal fin rays two; depth of body $17.0-17.6 \% \mathrm{SL}$ & compressus \\
\hline & (ii) Simple dorsal fin rays four; depth of body $20.4-24.6 \%$ SL & tengchongensis \\
\hline \multirow{2}{*}{ (14) } & (i) Rostral lobe absent, chest, and abdomen naked & Paralissorhynchus \\
\hline & (ii) Rostral lobe present, chest, and abdomen scaled & namyaensis \\
\hline
\end{tabular}

from G. poecilura in having a distinct W-shaped black band (versus two vertical rows of black spots) across the middle of caudal fin, two (versus three) unbranched dorsal fin rays, and a shorter (19.7-24.9\% SL versus 26.0-27.2) and narrower (18.0-20.0\% SL versus 21.7-22.5) head.

The presence of a prominent triangular-shaped rostral lobe on the snout easily distinguishes Garra namyaensis sp. nov from all its congeners except G. poecilura of the Chindwin-Irrawaddy basin and G. rakhinica Kullander and Fang, 2004, G. propulvinus Kullander and Fang, 2004, G. flavatra, G. vittatula Kullander and Fang, 2004, and G. nigricollis Kullander and Fang, 2004 of the rivers draining the western face of the Rakhine Yoma. The new species can be easily distinguished from G. flavatra and G. poecilura in the differences of the caudal markings as mentioned above and from the rest in the presence (versus absence) of a W-shaped band on the caudal fin. The new species further differs from G. poecilura in having tubercles scattered both on the snout and the rostral lobe (versus tubercles restricted to rostral lobe only) and 31 (versus 29) lateral line scales; from G. propulvinus in having two (versus three) unbranched dorsal fin rays, 12 (versus 13) branched pectoral fin rays and 13 (versus 10) predorsal scales; from G. rakhinica in having two (versus three) unbranched dorsal fin rays, a shorter dorsal fin (21.0-22.2\% SL versus 28.7-32.3) and 31 (versus 28) lateral line scales; from G. nigricollis in having 31 (versus 33) lateral line scales, 12 (versus 15) branched pectoral fin rays, a shorter dorsal fin (21.0-22.2\% SL versus 28.4-29.8), and 13 (versus 11) predorsal scales; from G. vittatula in having a shorter caudal peduncle (13.3-15.2\% SL versus 16.0-19.1), two (versus three) unbranched dorsal fin rays, and 12 (versus 14) branched pectoral fin rays; from G. flavatra in having narrower head (18.0-20.0\% SL versus 21.4-24.7), a shorter pelvic fin (18.3-20.0\% SL versus 22.2-24.7), and 31 (versus 28) lateral line scales.

A thorough revision of the species of Garra is required since no types have been designated for many of the described species, and also there are taxonomic ambiguities of some nominal species. In addition, molecular studies would clarify the species status of the described species and also help in understanding the phylogenetic relationship among the species. 


\section{Acknowledgments}

B. Shangningam is grateful to University Grants Commission (UGC) for providing University Research Scholarship, and W. Vishwanath is grateful to the Department of Science and Technology, Government of India (Project no. SR/SO/AS50/2008).

\section{References}

[1] A. G. K. Menon, "Monograph of the cyprinid fishes of the genus Garra Hamilton," Memoirs of the Indian Museum, vol. 4, no. 4, pp. 173-260, 1964.

[2] S. O. Kullander and F. Fang, "Seven new species of Garra (Cyprinidae: Cyprininae) from the Rakhine Yoma, southern Myanmar," Ichthyological Exploration of Freshwaters, vol. 15, no. 3, pp. 257-278, 2004.

[3] W. Eschmeyer and R. Fricke, "Catalog of Fishes," 2011, http://research.calacademy.org/redirect?url=http://research archive.calacademy.org/research/Ichthyology/catalog/ fishcatmain.asp.

[4] E. Zhang, S. P. He, and Y. Y. Chen, "Revision of the cyprinid genus Placocheilus Wu, 1977 in China, with description of a new species from Yunnan," Hydrobiologia, vol. 487, pp. 207217, 2002.

[5] T. R. Roberts, "The freshwater fishes of Western Borneo (Kalimantan, Barat, Indonesia)," Memoirs of the California Academy of Science, vol. 14, pp. 1-210, 1989.

[6] M. Kottelat, Fishes of Laos, Wildlife Heritage Trust, Colombo, Sri Lanka, 2001.

[7] S. L. Hora, "Indian cyprinoid fishes belonging to the genus Garra, with notes on related species from other countries," Records of the Indian Museum, vol. 22, no. 5, pp. 633-687, 1921.

[8] W. Vishwanath and I. Linthoingambi, "Redescription of Garra abhoyai Hora (Teleostei: Cyprinidae: Garrinae) with a note on Garra rupecula from Manipur, India," Journal of the Bombay Natural History Society, vol. 105, no. 1, pp. 101-104, 2008.

[9] W. Vishwanath and K. D. Shanta, "A new fish species of the genus Garra Hamilton-Buchanan (Cypriniformes: Cyprinidae) from Manipur, India," Journal of the Bombay Natural History Society, vol. 102, no. 1, pp. 86-88, 2005.

[10] W. Vishwanath and H. Joyshree, "A new species of genus Garra Hamilton-Buchanan (Teleostei: Cyprinidae) from Manipur, India," Zoos' Print Journal, vol. 20, no. 4, pp. 1832-1834, 2005. 

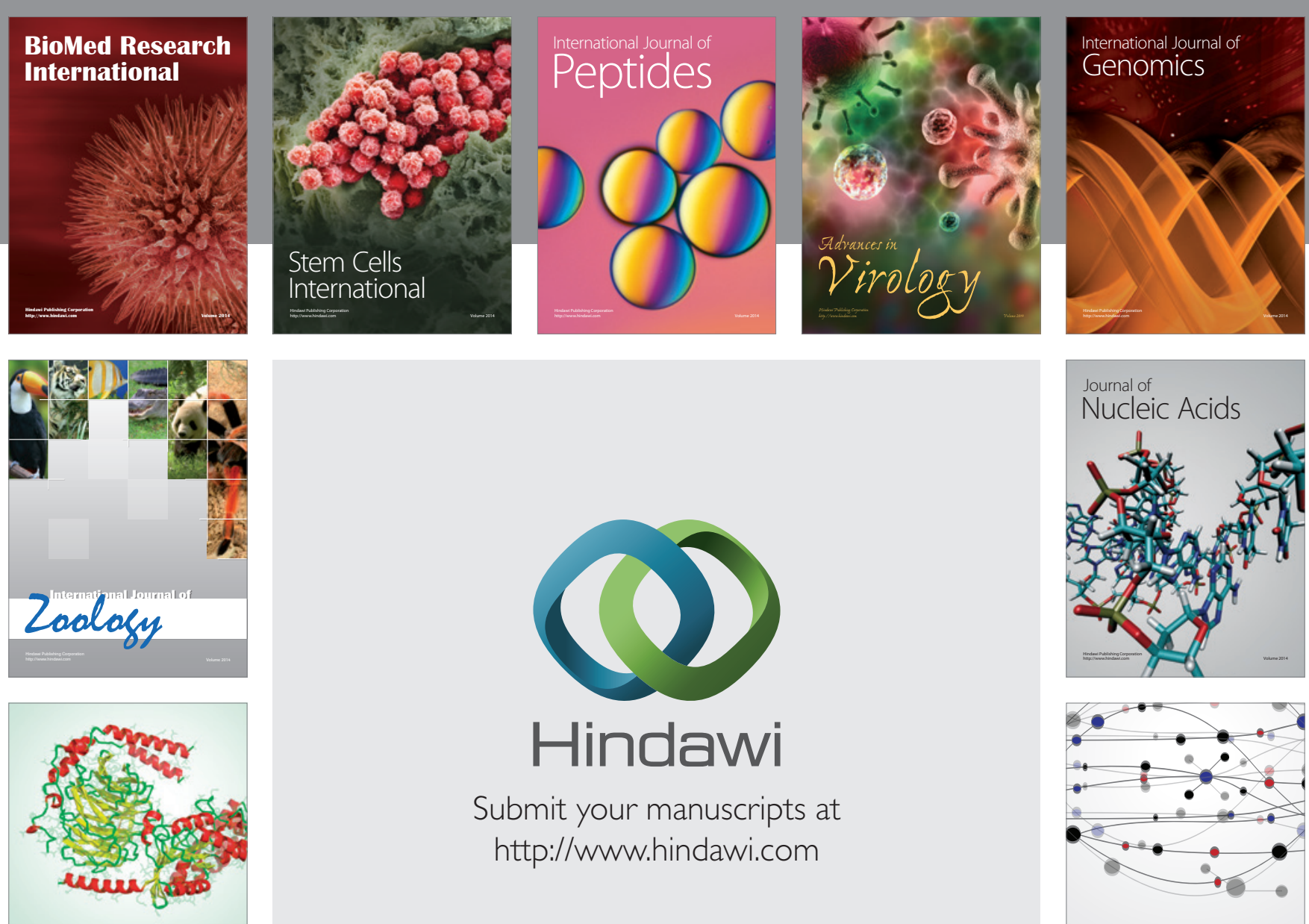

Submit your manuscripts at

http://www.hindawi.com

Signal ${ }^{\text {Jumal }}$ Transduction
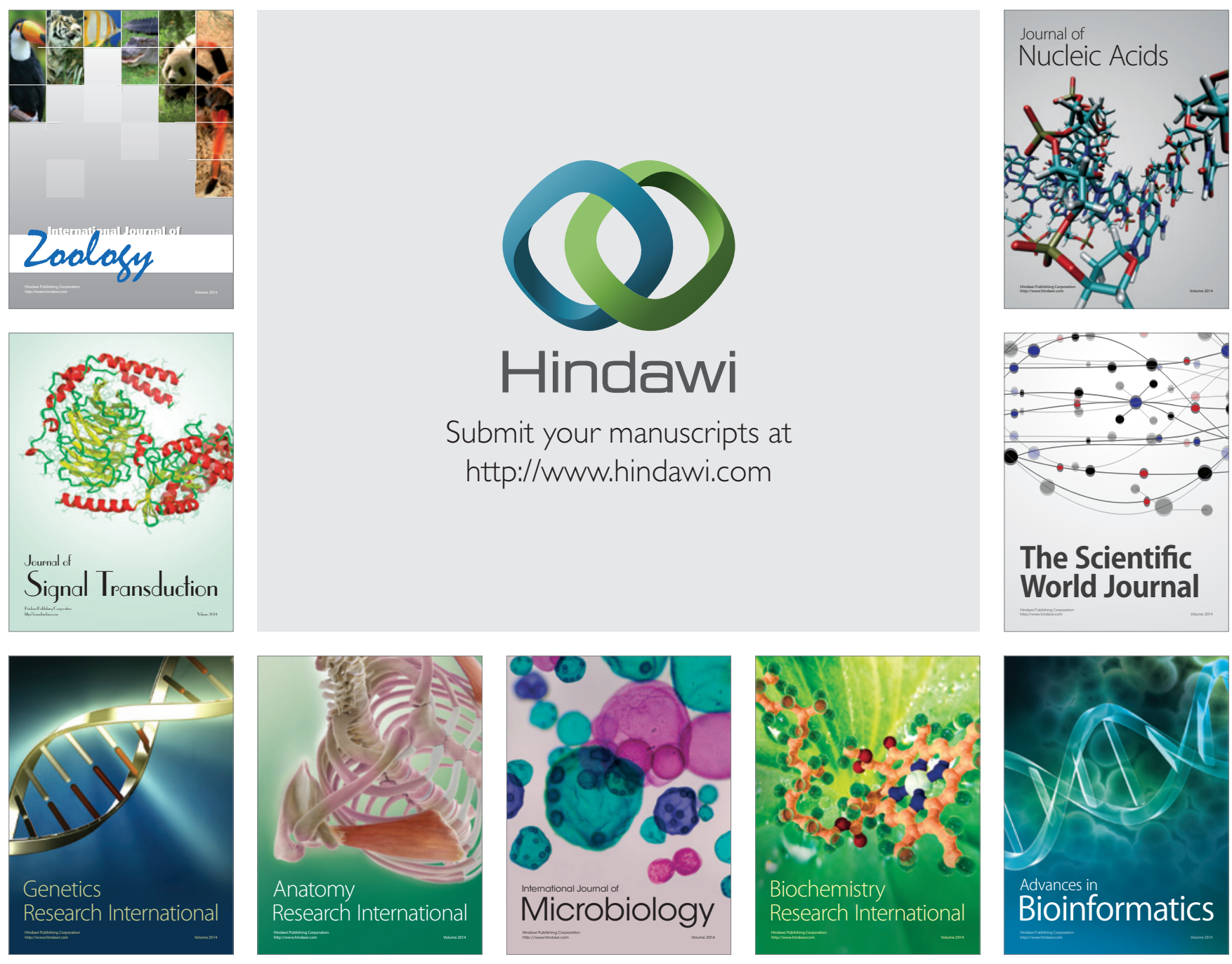

The Scientific World Journal
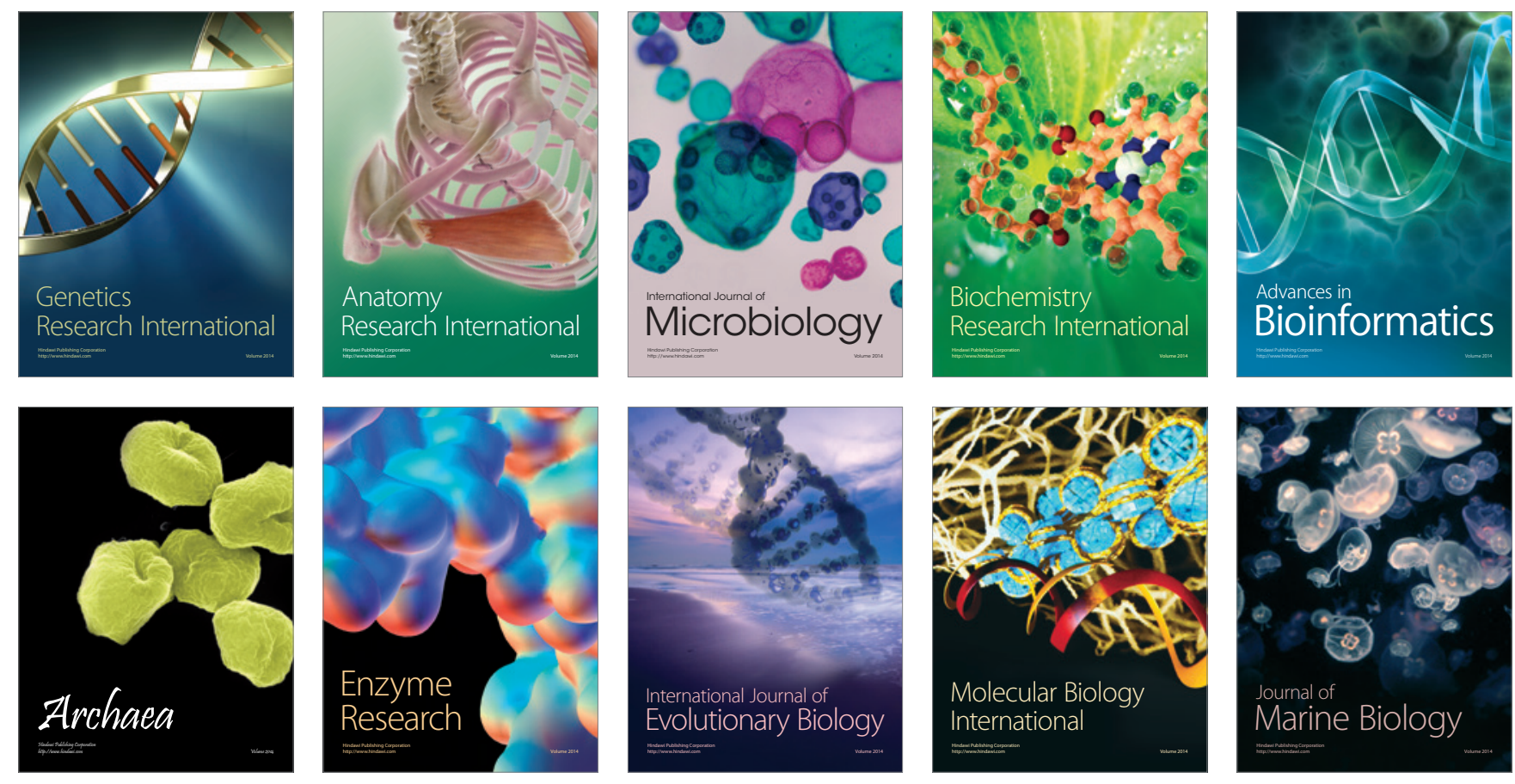